\title{
Pengaruh Efikasi Diri dan Ekspektasi Pendapatan, terhadap Minat Berwirausaha Siswa SMK (SMK Al-Madina)
}

\author{
Muslihudin $^{1}$, Anita Ilmaniati ${ }^{2}$ \\ ${ }^{1,2}$ Teknik Industri, Universitas Suryakancana \\ Jl. Pasir Gede Raya, Cianjur \\ 1ucehwellu49@gmail.com, ${ }^{2}$ anita.ilmaniati@gmail.com
}

Dikirimkan: 10, 2017. Diterima: 12, 2017). Dipublikasikan: 12, 2017.

\begin{abstract}
Cianjur regency is an area that has the potential to develop the regional economy through creative industries-based entrepreneurship. Cianjur is supported by many vocational schools (SMK) with relevant expertise fields to develop regional potential through entrepreneurship. Based on this, it is very important to develop entrepreneurship interest in SMK students in Cianjur by identifying factors that influence student entrepreneur interest. Factors of entrepreneur interest identified in this research are self efficacy and income expectation. The purpose of this research is to analyze the effect of self efficacy and income expectation on student entrepreneurship interest of SMK (Al-Madina, Cianjur). This research was conducted by distributing questionnaires to students of SMK Al-Madina Cianjur and using PLS-SEM model in testing. The results showed that the relationship of self efficacy variable to entrepreneurship interest was significant with T-statistics of 2,996 (> 1,96), and the relationship of income expectation variable to entrepreneur interest was significant with T-statistic 4,121 (> 1,96). R-Square value of this research model is 0.228 which shows that there are still other variables that will explain student entrepreneur interest in Cianjur.
\end{abstract}

Keywords: Self efficacy; income expectations; entrepreneurial interest; PLS-SEM

\begin{abstract}
Abstrak- Kabupaten Cianjur merupakan wilayah yang memiliki potensi untuk mengembangkan perekonomian daerah melaui kewirausahaan berbasis industri kreatif. Cianjur didukung oleh banyaknya SMK dengan bidang studi keahlian yang relevan untuk mengembangkan potensi daerah melalui kewirausahaan. Berdasarkan hal tersebut, sangat penting untuk megembangkan minat berwirausaha pada siswa SMK di Cianjur dengan mengidentifikasi faktor-faktor yang mempengaruhi minat berwirausaha siswa. Faktor dari minat berwirausaha yang diidentifikasi dalam penelitian ini adalah efikasi diri dan ekspektasi pendapatan. Tujuan dari penelitian ini adalah untuk menganalisis besar pengaruh efikasi diri dan ekpektasi pendapatan terhadap minat berwirausaha siswa SMK (Al-Madina, Cianjur). Penelitian ini dilakukan dengan menyebarkan kuesioner kepada siswa SMK Al-Madina Cianjur dan menggunakan model PLS-SEM dalam pengujian. Hasil penelitian menunjukan bahwa hubungan variabel efikasi diri terhadap minat berwirausaha adalah signifikan dengan T-statistik sebesar $2,996(>1,96)$, dan hubungan variabel ekspektasi pendapatan terhadap minat wirausaha adalah signifikan dengan T-statistik sebesar 4,121 (> 1,96). Nilai R-Square model penelitian ini yaitu 0.228 yang menunjukan bahwa masih terdapat variabel-variabel lain yang akan menjelaskan minat berwirausaha siswa di Cianjur.
\end{abstract}

Kata kunci: Efikasi diri; ekspektasi pendapatan; minat berwirausaha; PLS-SEM

\section{PENDAhULUAN}

\subsection{Latar Belakang}

Berdasarkan data dari Badan Pusat Statistik (BPS) pengangguran yang berasal dari lulusan SMK mencapai 1,1 juta orang pada tahun 2013. Penyebab banyaknya pengangguran lulusan SMK, selain karena rendahnya jumlah lulusan yang melanjutkan ke perguruan tinggi, penyebab lainnya adalah ketidakmampuan para lulusan SMK di Indonesia tersebut untuk menciptakan lapangan kerja.

Kabupaten Cianjur merupakan wilayah yang memiliki potensi untuk mengembangkan perekonomian daerah melaui kewirausahaan berbasis industri kreatif. Sesuai dengan instruksi presiden (inpres) NO. 6/2009 tentang pengembangan ekonomi kreatif di Indonesia bahwa SMK merupakan salah satu elemen 
pendidikan yang sangat penting dalam mendukung pengembangan ekonomi kreatif. Cianjur didukung oleh banyaknya SMK dengan bidang studi keahlian yang relevan untuk mengembangkan potensi daerah melalui kewirausahaan.

Kewirausahaan adalah semangat, sikap, perilaku dan kemampuan seseorang dalam menangani usaha atau kegiatan yang mengarah kepada upaya mencari, menciptakan, menerapkan cara kerja, teknologi dan produk baru dengan meningkatkan efisiensi dalam rangka memberikan pelayanan yang lebih baik dan atau memperoleh keuntungan yang lebih besar.

Berdasarkan definisi kewirausahaan tersebut, dapat disimpulkan bahwa seorang wirausaha harus mampu melihat adanya peluang, menganalisa peluang dan mengambil keputusan untuk mencapai keuntungan yang berguna bagi dirinya sendiri atau lingkungan sekitarnya dan kelanjutan usahanya sebelum peluang tersebut dimanfaatkan oleh orang lain. Kewirausahaan yang berhasil akan memacu sebuah mimpi dan berusaha merealisasikan mimpi tersebut karena adanya kepercayaan yang tinggi akan kesuksesan yang dapat diraih. Kewirausahaan akan sangat terkait oleh efikasi diri dan juga ekpektasi pendapatan dari seorang individu.

Efikasi diri mengacu pada keyakinan akan kemampuan-kemampuan yang dimiliki individu untuk menggerakkan motivasi, kemampuan kognitif dan tindakan-tindakan yang diperlukan untuk memenuhi tuntutan situasi. Jadi, efikasi diri berperan penting dalam menentukan keberhasilanseseorang dalam tugas tertentu atau pekerjaan tertentu seperti berwirausaha. Efikasi diri akan memungkinkan tumbuhnya keyakinan dari dalam diri individu sehingga dapat membantu melakukan aktivitasnya tanpa ada hambatan dan halangan apapun.

Ekspektasi pendapatan dapat berpengaruh terhadap minat berwirausaha. Semakin tinggi ekspektasi pendapatan individu, diperkirakan akan semakin tinggi pula minat berwirausaha, karena individu tersebut akan memiliki kontrol penuh terhadap usaha yang dijalankan termasuk dalam menentukan pendapatannya sendiri. Ekspektasi pendapatan yaitu harapan untuk memperoleh penghasilan lebih tinggi.

Sekolah Menengah Kejuruan (SMK) merupakan salah satu sekolah kejuruan swasta yang berada di Kabupaten Cianjur. SMK AlMadina didirikan sejak tahun 2008 dan telah mendapatkan predikat akreditasi A. SMK Al-
Madina memiliki 4 bidang kejuruan yang terdiri dari:

1. Administrasi Perkantoran (AP)

2. Teknik Komputer dan Jaringan (TKJ)

3. Teknik Kendaraan Ringan (TKR)

4. Teknologi Pengolah Hasil Pertanian (TPHP)

Bidang kejuruan yang terdapat di SMK AlMadina tersebut merupakan bidang yang dapat menunjang siswa dalam berwirausaha dengan keterampilan-keterampilan spesifik pada masingmasing bidang tersebut. Berdasarkan hal tersebut, penelitian ini menjadikan siswa SMK Al-Madina Cianjur sebagai obyek penelitian.

\subsection{Tujuan Penelitian}

Tujuan dari penelitian ini yaitu:

1. Menganalisis seberapa besar pengaruh efikasi diri terhadap minat berwirausaha di SMK AlMadina Cianjur.

2. Menganalisis seberapa besar pengaruh ekpektasi pendapatan terhadap minat berwirausaha di SMK Al-Madinah Cianjur.

1.3 Sistematika Penulisan

Makalah ini disusun dengan susunan sebagai berikut:

- Pendahuluan

- Metodologi Penelitian

- Hasil Penelitian

- Pembahasan

- Kesimpulan

\section{Metodologi Penelitian}

Penelitian dilakukan melalui beberapa tahapan yang secara umum terdiri dari:

1. Studi literatur

2. Penyusunan kuesioner

3. Pengumpulan data

4. Pengolahan data

\subsection{Studi Literatur}

Studi literatur pada penelitian ini dilakukan sebagai dasar dalam menentukan hipotesis penelitian. Hipotesis dalam penelitian ini yaitu menghubungkan faktor efikasi diri dan ekspektasi pendapatan terhadap minat berwirausaha dari siswa SMK Al-Madina.

\subsubsection{Minat Berwirausaha}

Berdasarkan Inpres No. 4 tahun 1995, Kewirausahaan adalah semangat, sikap, perilaku dan kemampuan seseorang dalam menangani usaha atau kegiatan yang mengarah kepada upaya mencari, menciptakan, menerapkan cara kerja, teknologi dan produk baru dengan meningkatkan efisiensi dalam 


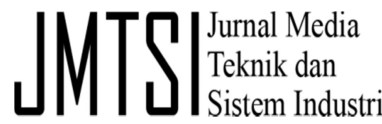

rangka memberikan pelayanan yang lebih baik dan atau memperoleh keuntungan yang lebih besar [1]

Menurut [2], ciri-ciri pribadi wirausaha yang paling sering diungkapkan adalah:

1) Adanya kebutuhan untuk mencapai sesuatu

2) Adanya kebutuhan akan kontrol, orientasi intuitif yang kreatif

3) Melihat ke masa depan

4) Kecenderungan untuk mengambil resiko.

5) Mempunyai kebebasan mental

6) Mempunyai jiwa kepemimpinan

7) Pemberontak sosial

Mc. Clelland dalam [3] menyatakan karakteristik wirausaha sebagai berikut:

1. Keinginan untuk berprestasi

2. Keinginan untuk bertanggung jawab

3. Preferensi kepada resiko-resiko menengah

4. Persepsi pada kemungkinan berhasil

5. Rangsangan oleh umpan balik

6. Aktivitas energik

7. Orientasi ke masa depan

8. Ketrampilan dalam pengorganisasian.

9. Sikap terhadap uang

Pendidikan tingkat menengah, khususnya SMK memiliki karakter yang unik dalam menghasilkan lulusan yang siap kerja, namun memiliki peluang besar untuk ikut mengembangkan ekonomi melalui kewirausahaan. Siswa SMK yang sedang menempuh pendidikan harus dipersepsikan tidak hanya untuk mengisi peluang kerja sebagai pekerja pada dunia usaha dan industri, akan tetapi juga upaya pendidikan yang memberikan lulusan SMK memiliki jiwa dan perilaku karakteristik kewirausahaan.

\subsubsection{Efikasi Diri}

Efikasi diri mengacu pada keyakinan akan kemampuan-kemampuan yang dimiliki individu untuk menggerakkan motivasi, kemampuan kognitif dan tindakan-tindakan yang diperlukan untuk memenuhi tuntutan situasi. Efikasi diri akan memungkinkan tumbuhnya keyakinan dari dalam diri individu sehingga dapat membantu melakukan aktivitasnya tanpa ada hambatan dan halangan apapun.

Efikasi diri dapat diperoleh, diubah, ditingkatkan dan di turunkan, melalui salah satu atau beberapa kombinasi empat sumber. Menurut [4] ada empat sumber penting yang digunakan individu dalam membentuk efikasi diri yaitu :
a) Mastery
Experience
(pengalaman

keberhasilan)

b) Vicarious Experience (pengalaman meniru keberhasilan orang lain)

c) Social Persuasion (informasi tentang kemampuan yang disampaikan secara verbal)

d) Physiological \& Emotion State (status psikologis dan emosi)

Efikasi diri terkait dengan kemampuan untuk menyelesaikan tugas, memenuhi tuntutan, bertanggung jawab, mencapai tujuan, dan menuju kesuksesan dapat menjadi dasar keyakinan bagi siswa untuk membuka usaha sendiri di masa depan. Sebaliknya, siswa yang tidak memiliki keyakinan atau efikasi diri terkait hal diatas diperkirakan akan memiliki minat berwirausaha yang rendah.

Berdasarkan uraian diatas, penelitian ini merumusukan hipotesis sebagai berikut:

H1: Efikasi diri berpengaruh secara positif dan signifikan terhadap minat berwirausaha siswa SMK Al-madina.

\subsubsection{Ekspektasi Pendapatan}

Ekspektasi pendapatan yaitu harapan untuk memperoleh penghasilan lebih tinggi, sehingga dengan ekspektasi pendapatan yang lebih tinggi maka akan semakin meningkatkan minat berwirausaha pada siswa [1]. Menjadi wirausaha akan memperoleh keuntungan yang besar. Berwirausaha dapat memperoleh penghasilan yang tinggi dan tidak terbatas sesuai harapanya sehingga memenuhi segala keinginannya [5]. Keinginan untuk memperoleh pendapatan tak terbatas itulah yang dianggap dapat menimbulkan minat berwirausaha.

Berdasarkan uraian diatas dapat disimpulkan bahwa semakin tinggi ekpektasi pendapatan seseorang maka minat untuk berwirausaha akan semakin tinggi. Oleh karena itu, dirumuskan hipotesis sebagai berikut:

H2: Ekspektasi pendapatan berpengaruh secara positif dan signifikan tergadap minat berwirausaha siswa SMK Al-madina.

\subsubsection{Model Strktural Penelitian}

Berdasarkan pada studi literatur dan hipotesis penelitian yang telah dirumuskan, maka model penelitian dari penenlitian ini adalah seperti yang digambarkan pada Gambar 1 .

\subsection{Penyusunan Kuesioner}

Pengumpulan data akan dilakukan dengan menggunakan kuesioner yang berisi item-item pernyataan untuk mengukur faktor efikasi diri, ekpektasi pendapatan, dan minat berwirausaha. 
Item-item yang digunakan akan diberi nilai rating oleh responden dengan menggunakan skala likert 1-5.

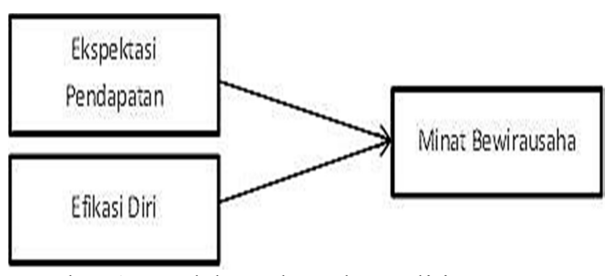

Gambar 1. Model Struktural Penelitian

Item pernyataan untuk efikasi diri mengacu pada penelitian [6] yang menggunakan delapan item pernyataan untuk faktor efikasi diri. Beberapan pernyataan yang digunakan pada penelitian disesuaiakan agar lebih sesuai bagi siswa SMK. Item pernyataan faktor efikasi diri tercantum pada Tabel 1.

TABEL I

ITEM PERNYATAAN FAKTOR EFIKASI DIRI

\begin{tabular}{|l|l|l|}
\hline No. & \multicolumn{1}{|c|}{ Item Pernyataan } & Kode \\
\hline 1 & $\begin{array}{l}\text { Saya memiliki keyakinan diri atas } \\
\text { kemampuan yang dimiliki dalam } \\
\text { menghadapi berbagai tugas }\end{array}$ & ED1 \\
\hline 2 & $\begin{array}{l}\text { Saya membangun diri saya untuk } \\
\text { memenuhi tuntutan sebagai siswa }\end{array}$ & ED2 \\
\hline 3 & $\begin{array}{l}\text { Saya memiliki keteknan dalam } \\
\text { mencapai tujuan }\end{array}$ & ED3 \\
\hline 4 & $\begin{array}{l}\text { Saya mampu bertanggung jawab } \\
\text { pada saat kegiatan praktik }\end{array}$ & ED4 \\
\hline 5 & $\begin{array}{l}\text { Keberhasilan yang pernah dialami } \\
\text { membuat saya yakin akan } \\
\text { kemampuan saya untuk menjadi } \\
\text { sukses mes }\end{array}$ & ED5 \\
\hline 6 & $\begin{array}{l}\text { Saya memiliki keyakinan bawa } \\
\text { besarnya usaha yang dilakukan } \\
\text { akan menentukan tercapainya } \\
\text { tujuan En }\end{array}$ & ED6 \\
\hline 7 & $\begin{array}{l}\text { Saya yakin memiliki kemampuan } \\
\text { diri dalam mengatasi masalah- } \\
\text { masalah antar sesama individu }\end{array}$ & ED7 \\
\hline 8 & $\begin{array}{l}\text { Saya berusaha untuk dapat } \\
\text { mengatasi tugas-tugas yang } \\
\text { memiliki tingkat kesulitan tinggi }\end{array}$ & ED8 \\
\hline
\end{tabular}

Item pernyataan untuk faktor ekspektasi pendapat mengacu pada penelitian [7] yang menggunakan empat item pernyataan seperti yang tercantum pada Tabel 2 .

Item pernyataan untuk faktor minat berwirausaha mengacu pada penelitian [8] dan [9], sehingga menggunakan empat item pernyataan untuk mengukur faktor minat berwirausaha. Item pernyataan untuk faktor minat berwirausaha seperti pada Tabel 3 dibawah ini.
TABEL II

ITEM PERNYATAAN FAKTOR EKSPEKTASI PENDAPATAN

\begin{tabular}{|c|l|c|}
\hline No. & \multicolumn{1}{|c|}{ Item Pernyataan } & Kode \\
\hline 1 & $\begin{array}{l}\text { Dengan menjadi seorang } \\
\text { wirausaha, saya akan } \\
\text { memperoleh pendapatan lebih } \\
\text { besara daripada pekerja }\end{array}$ & EP9 \\
\hline 2 & $\begin{array}{l}\text { Pendapatan yang tinggi } \\
\text { merupakan motivasi saya untuk } \\
\text { menjadi wirausaha }\end{array}$ & EP10 \\
\hline 3 & $\begin{array}{l}\text { Menjadi wirausaha akan } \\
\text { memperoleh pendapatan yang } \\
\text { tidak terbatas }\end{array}$ & EP11 \\
\hline 4 & $\begin{array}{l}\text { Pendapatan yang tidak terbatas } \\
\text { merupakan motivasi saya untuk } \\
\text { berwirausaha }\end{array}$ & EP12 \\
\hline
\end{tabular}

TABEL III

ITEM PERNYATAAN FAKTOR MINAT BERWIRAUSAHA

\begin{tabular}{|c|l|c|}
\hline No. & \multicolumn{1}{|c|}{ Item Pernyataan } & Kode \\
\hline 1 & $\begin{array}{l}\text { Saya ingin bekerja atau berprofesi } \\
\text { sebagai pengusaha (entrepeneur) }\end{array}$ & MW13 \\
\hline 2 & $\begin{array}{l}\text { Saya sering mencari informasi yang } \\
\text { berhubungan dengan kewirausahaan } \\
\text { karena saya ingin segera membuka } \\
\text { dan menjalankan usaha saya sendiri } \\
\text { (berwirausaha) }\end{array}$ & MW14 \\
\hline 3 & $\begin{array}{l}\text { Saya memilih berwirausaha sebagai } \\
\text { karir saya }\end{array}$ & MW15 \\
\hline 4 & $\begin{array}{l}\text { Saya bertekad untuk memulai usaha } \\
\text { sendiri }\end{array}$ & MW16 \\
\hline
\end{tabular}

Berdasarkan pada item-item pernyataan yang digunakan, maka penelitian ini menggunakan total 16 indikator dalam mengukur model penelitian. Jumlah indikator tersbut dianggap sudah cukup karena model penelitian yang digunakan cukup sederhana dengan dua jalur hubungan yang akan diestimasi. Model pengukuran penelitian ditunjukan seperti seperti pada Gambarr 2 dibawah ini.

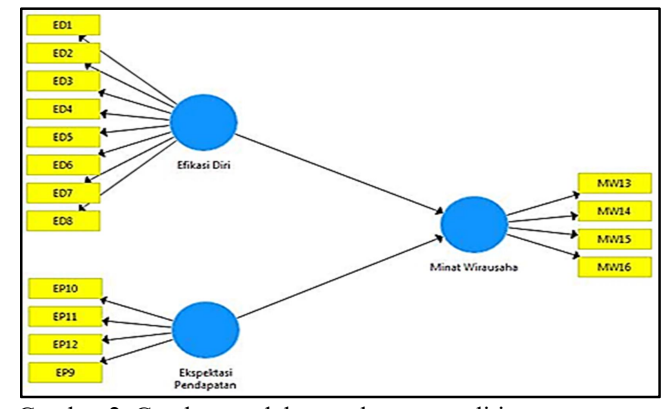

Gambar 2. Gambar model pengukuran penelitian 


\section{JMTS|}

\subsection{Pengumpulan Data}

Pengumpulan data terdiri atas dua tahap yaitu pengumpulan data awal dan pengumpulan data primer penelitian. Pengumpulan data primer penelitian dilakukan dengan menyebarkan kuesioner pada siswa-siswa SMK Al-Madina. Total populasi siswa SMK AlMadina pada tahun ajaran 2016/2017 adalah 382 siswa (kelas X 183 siswa, kelas XI 96 siswa dan kelas XII 103 siswa) dari seluruh jurusan. Pengambilan sampel penelitian diambil dengan teknik random sampling tanpa mempertimbangkan proporsi siswa berdasarkan tingkat kelas dan jurusan.

Data responden yang terkumpul adalah sebanyak 96 siswa atau kurang lebih 25\% dari populasi. Responden tersebut terdiri dari 53 siswa laki-laki dan 43 siswa perempuan, dengan responden terbanyak adalah siswa jurusan administrasi perkantoran sebanyak 39 siswa (41\%). Siswa yang menjadi responden pada penelitian ini hanya siswa kelas X dan XII karena siswa kelas XI berhalangan untuk mengisi kuesioner saat pengumpulan data dilakukan.

\subsection{Pengolahan Data}

Pengolahan data dilakukan dengan melakukan analisis jalur (path analysis) secara statistik untuk mengestimasi parameter atau nilai koefisien regresi pada dua variabel independen (faktor efikasi diri dan ekspektasi pendapatan). Metode estimasi yang digunakan adalah metode Partial Least Square (PLS) karena dapat dijalankan dengan jumlah sampel yang relatif kecil dan tidak memerlukan asumsiasumsi.

Perangkat lunak yang digunakan pada penelitian ini adalah SmartPLS 3 yang umumnya dignakan untuk mengolah data dari model penelitian berupa structural equation modelling (SEM) dengan metode estimasi PLS. Meskipun model penelitian ini adalah merupakan model regresi sederhana dan bukan merupakan model SEM, pengolahan data tetap dilakukan sengan SmartPLS karena semua variabel yang diukur adalah variabel laten yang tidak dapat diukur secara langsung.

Pengolahan data dalam penelitian ini dilakukan dalam beberapa tahap berdasarkan pengujian yang dilakuakan, yaitu:

1) Pengujian validitas dan reliabilitas model awal

2) Pengujian signifikansi indikator model awal

3) Pengujian validias dan reliabilitas model perbaikan
4) Pengujian signifikansi indikator model perbaikan

5) Pengujian kebaikan model struktural ( $R$ square)

6) Pengujian hipotesis (signifikansi model struktural)

\section{HASIL PENELITIAN}

Hasil penelitian ditampilkan berdasarkan urutan pengujian yang dilakukan.

\subsection{Pengujian Validitas dan Reliabilitas Model} Awal

Pengujian validitas adalah untuk menguji apakah setiap indikator (item pernyataan) valid dalam mengukur variabel laten yang diukur. Pengujian validitas dalam penelitian ini menggunakan output cross loading dan average variance extracted (AVE).

TABEL IV

OUTPUT CROSS LOADING

\begin{tabular}{|c|c|c|c|}
\hline & ED & EP & MW \\
\hline ED1 & 0.379 & 0.179 & 0.091 \\
\hline ED2 & 0.523 & 0.119 & 0.103 \\
\hline ED3 & 0.336 & -0.007 & 0.106 \\
\hline ED4 & 0.610 & -0.036 & 0.211 \\
\hline ED5 & 0.777 & 0.109 & 0.282 \\
\hline ED6 & 0.137 & -0.02 & 0.245 \\
\hline ED7 & -0.025 & 0.077 & -0.044 \\
\hline ED8 & 0.039 & 0.073 & -0.007 \\
\hline EP9 & -0.131 & 0.557 & 0.115 \\
\hline EP10 & 0.166 & 0.832 & 0.377 \\
\hline EP11 & -0.045 & 0.589 & 0.086 \\
\hline EP12 & 0.032 & 0.681 & 0.256 \\
\hline MW13 & 0.388 & 0.218 & 0.619 \\
\hline MW14 & 0.055 & 0.217 & 0.540 \\
\hline MW15 & 0.108 & 0.329 & 0.767 \\
\hline MW16 & 0.257 & 0.269 & 0.766 \\
\hline
\end{tabular}

Matriks cross loading memberikan informasi mengenai korelasi indikator dengan variabel laten. Jika suatu indikator memiliki korelasi yang lebih tinggi dengan variabel laten lain dibandingkan dengan variabel yang diukurnya, maka kesesuaian model perlu dipertimbangkan kembali. Berdasarkan output cross loading pada Tabel IV tersebut, indikator ED7 dan ED8 merupakan indikator yang perlu untuk diertimbangkan kembali untuk mengukur faktor efikasi diri. 
TABEL V

OutPut AVERAge VARIANCE ExtRacted (AVE)

\begin{tabular}{|c|c|}
\hline Variabel & Nilai AVE \\
\hline ED & 0.197 \\
\hline EP & 0.453 \\
\hline MW & 0.462 \\
\hline
\end{tabular}

Nilai AVE diatas 0,5 menunjukan bahwa validitas dari variabel yang diukur baik. Berdasarkan nilai AVE pada Tabel V, ketiga variabel (efikasi diri, ekspektasi pendapatan, minat berwirausaha) belum memiliki validitas yang baik. Nilai terendah AVE adalah sebesar 0,197 pada konstruk ED (Efikasi Diri).

Nilai composite reliability, dan Cronbach's $\alpha$ adalah kriteria untuk mengevaluasi reliabilitas model pengukuran. Tabel VI dan VII menunjukan nilai composite reliability, dan Cronbach's $\alpha$.

TABEL VI

OUTPUT COMPOSITE RELIABILITY

\begin{tabular}{|c|c|}
\hline Variabel & Composite Reliability \\
\hline ED & 0.566 \\
\hline EP & 0.764 \\
\hline MW & 0.566 \\
\hline
\end{tabular}

Reliabilitas model dianggap baik jika nilai composite reliability diatas 0.7 , dan dianggap kurang jika nilai composite reliability dibawah 0.6. Berdasarkan output composite reliability, diketahui bahwa variabel efikasi diri dan minat berwirausaha memiliki reliabilitas yang kurang baik.

TABEL VII

OUTPUT CRONBACH'S ALPHA

\begin{tabular}{|c|c|}
\hline & Cronbach's Alpha \\
\hline ED & 0.618 \\
\hline EP & 0.638 \\
\hline MW & 0.384 \\
\hline
\end{tabular}

Reliabilitas model dianggap baik jika nilai cronbach's alpha diatas 0.7 , dan dianggap kurang jika nilainya dibawah 0.6. Berdasarkan output cronbach's alpha, diketahui bahwa seluruh variabel memiliki reliabilitas yang kurang baik. Variabel minat berwirausaha (MW) memiliki nilai cronbach's alpha yang paling kecil (0.384), sedangkan nilai cronbach's alpha dari variabel efikasi diri (ED) dan ekspektasi pendapatan (EP) cukup nilai 0,7 .

\subsection{Pengujian Signifikansi Indikator Model Awal}

Pengujian signifikansi indikator dilakukan dengan melihat nilai outer loading dari setiap indikator terhadap variabel yang diukurnya.
Signifikansi nilai outer loading ditentukan dengan nilai $t$-statisic $(>1,96)$ atau $p$-value $(>0,05)$. Pada SmartPLS, signifikansi indikator dapat diperoleh dari PLS algorithm result (tanpa nilai t-statistic dan $p$-value) atau bootstrapping result (dengan nilai t-statistic dan $p$-value). Tabel VII di bawah ini menunjukan nilai outer loading dari PLS algorithm result.

TABEL VIII

OUTPUT OUTER LOADING

\begin{tabular}{|c|c|c|c|c|}
\hline & ED & EP & MW & Keterangan \\
\hline ED1 & 0,379 & & & Tidak signifikan \\
\hline ED2 & 0,245 & & & Tidak signifikan \\
\hline ED3 & 0,336 & & & Tidak signifikan \\
\hline ED4 & 0,610 & & & Tidak signifikan \\
\hline ED5 & 0,777 & & & Signifikan \\
\hline ED6 & 0,523 & & & Tidak signifikan \\
\hline ED7 & 0,025 & & & Tidak signifikan \\
\hline ED8 & 0,039 & & & Tidak signifikan \\
\hline EP9 & & 0,681 & & Signifikan \\
\hline EP10 & & 0,832 & & Signifikan \\
\hline EP11 & & 0,589 & & Signifikan \\
\hline EP12 & & 0,557 & & Tidak signifikan \\
\hline MW13 & & & 0,619 & Tidak signifikan \\
\hline MW14 & & & 0,540 & Signifikan \\
\hline MW15 & & & 0,767 & Tidak signifikan \\
\hline MW16 & & & 0,766 & Signifikan \\
\hline
\end{tabular}

Berdasarkan signfikansi outer loading tersebut dapat diketahui bahwa sebagian besar indikator tidak memberikan nilai loading signfikan terhadap variabel yang diukurnya. Hal tersebut dapat disebabkan karena validitas dan reliabilitas indikator yang kurang baik.

\subsection{Pengujian Validitas dan Reliabilitas Model Perbaikan}

Berdasarkan hasil pengujian validitas dan reliabilitas pada model awal, dapat diketahui bahwa validitas dan reliabilitas variabel yang diukur belum cukup baik. Oleh karena hal tersebut, perlu dilakukan perbaikan model sebelum pengajuan model struktural dilakukan.

Perbaikan model dilakukan dengan membuang beberapa indikator berdasarkan hasil pengujian validitas dan reliabilitas pada model awal. Indikator yang dibuang pada model perbaikan didasari oleh nilai cross loading pada model awal (Tabel.IV). Berdasarkan hal tersebut, maka indiator ED7 dan ED6, ED7, ED8 dibuang. Tabel 


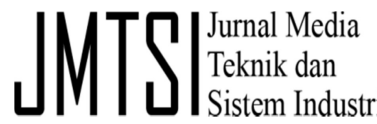

IX dan Tabel X menunjukan hasil cross loading dan nilai AVE untuk model perbaikan.

TABEL IX

OutPut CRoss LoAding Model PerbaiKan
\begin{tabular}{|c|c|c|c|}
\hline & ED & EP & MW \\
\hline ED1 & 0.428 & 0.178 & 0.091 \\
\hline ED2 & 0.340 & -0.005 & 0.106 \\
\hline ED3 & 0.642 & -0.307 & 0.208 \\
\hline ED4 & 0.793 & 0.108 & 0.277 \\
\hline ED5 & 0.510 & -0.022 & 0.133 \\
\hline EP6 & -0.146 & 0.559 & 0.117 \\
\hline EP7 & 0.043 & 0.688 & 0.262 \\
\hline EP8 & 0.141 & 0.825 & 0.372 \\
\hline EP9 & -0.044 & 0.593 & 0.090 \\
\hline MW10 & 0.370 & 0.215 & 0.605 \\
\hline MW11 & 0.080 & 0.220 & 0.564 \\
\hline MW12 & 0.095 & 0.328 & 0.771 \\
\hline MW13 & 0.236 & 0.268 & 0.762 \\
\hline
\end{tabular}

TABEL X

Output AVerage Variance Extracted (AVE) Model PERBAIKAN

\begin{tabular}{|c|c|}
\hline & Nilai AVE \\
\hline ED & 0.320 \\
\hline EP & 0.455 \\
\hline MW & 0.466 \\
\hline
\end{tabular}

Berdasarkan output pada tabel IX dan $\mathrm{X}$ tersebut, dapat diketahui bahwa nilai cross loading pada model perbaikan menjadi lebih baik tetapi nilai AVE tetap kurang baik. Tabel XI dan Tabel XII menunjukan output composite reliability dan cronbach's alpha pada model perbaikan.

TABEL XI

OutPut Composite ReLIABILITY Model Perbaikan

\begin{tabular}{|l|c|}
\hline & Nilai Composite Reliability \\
\hline ED & 0.680 \\
\hline EP & 0.765 \\
\hline MW & 0.774 \\
\hline
\end{tabular}

TABEL XII

Output CRonbach's Alpha Model Perbaikan

\begin{tabular}{|c|c|}
\hline & Cronbach's Alpha \\
\hline ED & 0.461 \\
\hline EP & 0.638 \\
\hline MW & 0.618 \\
\hline
\end{tabular}

Berdasarkan output pada tabel XI dan XII tersebut, dapat diketahui bahwa terjadi peningkatan nilai composite reliability dan cronbach's alpha walaupun masih terdapat nilai dibawah 0.7 .

\subsection{Pengujian Signifikansi Indikator Model Perbaikan}

Berikut adalah hasil outer loading dari masing-masing indikator terhadap variabel latennya dari model perbaikan, yang disajikan pada Tabel XII.

TABEL XIII

Output Outer Loading Model Perbaikan

\begin{tabular}{|c|c|c|c|c|}
\hline & ED & EP & MW & Keterangan \\
\hline ED1 & 0,426 & & & Tidak signifikan \\
\hline ED2 & 0,340 & & & Tidak signifikan \\
\hline ED3 & 0,642 & & & Signifikan \\
\hline ED4 & 0,793 & & & Signifikan \\
\hline ED5 & 0,510 & & & Tidak signifikan \\
\hline EP6 & & 0,559 & & Tidak signifikan \\
\hline EP7 & & 0,688 & & Signifikan \\
\hline EP8 & & 0,825 & & Signifikan \\
\hline EP9 & & 0,593 & & Signifikan \\
\hline MW10 & & & 0,605 & Tidak signifikan \\
\hline MW11 & & & 0,564 & Signifikan \\
\hline MW12 & & & 0,771 & Signifikan \\
\hline MW13 & & & 0,765 & Signifikan \\
\hline
\end{tabular}

Berdasarkan signfikansi outer loading tersebut dapat diketahui bahwa sebagian nilai outer loading meningkat dan menjadi signfikan, sedangkan sebagian lainnya tetap tidak signfikan. Meskipun validitas, reliabilitas, serta sebgaian signfikansi indikator tetap kurang baik, model perbaikan ini tetap digunakan sebagai model yang akan digunakan untuk analisis jalur dan pegujian hipotesis. Hal tersebut dilakukan karena pada model perbaikan selanjutnya (dengan membuang lebih banyak indikator) tidak didapatkan hasil yang lebih baik.

\subsection{Pengujian Kebaikan Model Struktual ( $R$ - square)}

Nilai R-square merupakan koefisien determinasi dari variabel endogen. Chin (1998) dalam [10] Henseler dkk. (2009) menggambarkan nilai R2 sebagai substansial/substantial $\quad( \pm \quad 0,67)$ sedang/moderate $( \pm 0,33)$, dan lemah/weak $( \pm$ 0,19). Model perbaikan dari penelitian ini memiliki nilai $0.228(22.8 \%)$ yang berada 
diantara level lemah/weak dan sedang/moderate.

\subsection{Pengujian Hipotesis Penelitian (signifikansi} model struktural)

Pengujian signfikansi model Struktural dilakukan berdasarkan pada output Bootstrapping result pada SmartPLS untuk melihat signfikansi hubungan variabel independen terhadap variabel dependen berdasarkan signifikansi nilai $t$-statistic, sehingga hipotesis penelitian dapat disimpulkan. Nilai $t$-statistic $>1,96$ atau $p$-value $<0,05$ menunjukan jalur hubungan yang signifikan. Tabel XIV menunjukan hasil pegujian signfikansi model penelitian.

TABEL XIV

Hasil Pengujian Hipotesis Model Penelitian

\begin{tabular}{|c|c|c|c|c|}
\hline & $\begin{array}{c}\text { Original } \\
\text { Sample }\end{array}$ & T-Stat & P-Value & Keterangan \\
\hline $\begin{array}{c}\text { Efikasi } \\
\text { Diri } \rightarrow \\
\text { Minat } \\
\text { Wirausaha }\end{array}$ & 0.292 & 2.966 & 0.003 & H1 diterima \\
\hline $\begin{array}{c}\text { Ekspektasi } \\
\text { Pendapatan } \\
\rightarrow \text { Minat } \\
\text { Wirausha }\end{array}$ & 0.357 & 4.121 & 0.005 & H2 diterima \\
\hline
\end{tabular}

Berdasarkan hasil pengujian sgnfikansi model struktural/pengujian hipotesis, diketahui bahwa hubungan efikasi diri (ED) dan ekspektasi pendapatan (EP) adalah positif dan signfikan. Hal tersebut ditunjukan oleh nilai koefisien (original sample) yang bernilai positif dan nilai p-value $<$ 0,05. Gambar 3 menunjukan hasil analisis jalur dari model penelitian.

\section{PEMBAHASAN}

Analisis kebaikan model pengukuran menunjukan bahwa model pengukuran setelah perbaikan (tanpa ED6, ED7, dan ED8) kurang dapat diterima karena sebagian variabel masih memiliki nilai reliabilitas $<0,7$ dan validitas $<$ 0,5, meskipun nilai cross loading sudah cukup baik. Selain itu, sebagian nilai outer loading indikator menunjukan hasil yang tidak signfikan, sehingga indikator-indikator dalam penelitian ini belum memberikan informasi yang cukup untuk mengukur variabel laten yang diukurnya.

Kurang diterimanya model pengukuran dalam penelitian ini dapat disebabkan karena kurang dimengertinya kalimat pernyataan (indikator) pada kuesioner oleh para siswa SMK sebagai responden penelitian. Kalimat pernyataan sebagai indikator harus disusun lebih sederhana sehingga lebih dimengerti oleh siswa.

Analisis kebaikan model struktural menunjukan bahwa model struktural setelah perbaikan model cukup dapat diterima karena
$0,19<R$-square $>0,33$ atau nilai $R$-square berada diantara level lemah dan sedang. Menurut [10] Henseler dkk. (2009), jika suatu model struktural menjelaskan variabel endogen hanya dengan satu atau dua variabel eksogen, maka nilai R2 dengan level sedang dapat diterima. Nilai $R$-square yang tidak terlalu tinggi menunjukan bahwa model penelitian belum mampu menjelaskan variabel minat berwirausaha (MW) dengan baik dan dasardasar teori yang digunakan perlu dipertanyakan kembali.

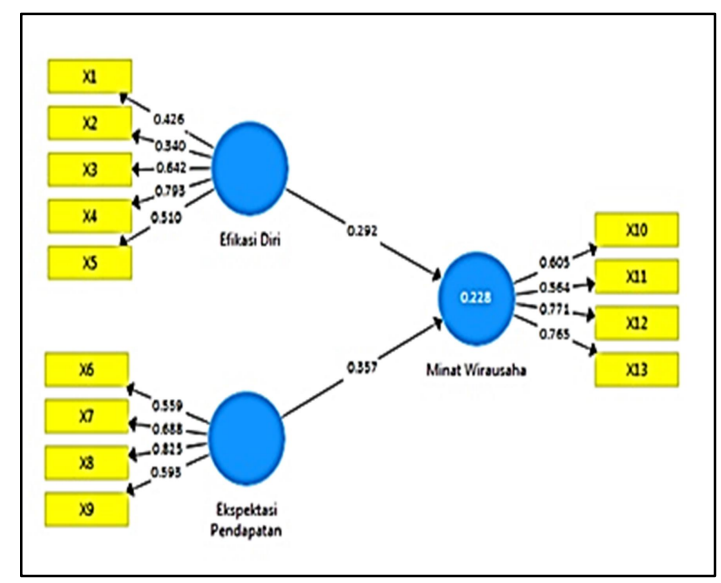

Gambar 3. Hasil analisis jalur model penelitian

Berdasarkan hasil uji hipotesis, diketahui bahwa $\mathrm{H} 1$ dan $\mathrm{H} 2$ dari penelitian ini diterima karena nilai p-value dari kedua jalur yang dianalisis (efikasi diri $\rightarrow$ minat berwirausaha; ekspektasi pendapatan $\rightarrow$ minat berwirausaha) adalah $<0.05$. Berdasarkan hal tersebut terbukti bahwa efikasi diri dan ekspektasi pendapatan berpengaruh secara signfikan dan positif terhadap minat berwirausaha siswa SMK Al-Madina. Penarikan kesimpulan berdasarkan uji hipotesis dari penenlitian ini tetap harus mempertimbangkan hasil dari pengujian model pengukuran, mengingat model pengukuran dari penelitian ini belum cukup diterima.

\section{KESIMPULAN}

1. Hubungan antara efikasi diri (ED) dengan minat berwirausaha (MW) adalah positif dengan koefisien sebesar 0,292 dan nilai Tstatistik sebesar 2,996 (>1,96), serta PValue sebesar 0,003 yang menunjukan bahwa hubungan antara ED dengan MW adalah signfikan. Dengan demikian hipotesis H1 dalam penelitian ini yang menyatakan bahwa Efikasi Diri berpengaruh positif dan signifikan terhadap Minat Wirausaha diterima 
2. Hubungan antara ekspektasi pendapatan (EP) dengan minat berwirausaha (MW) adalah positif dengan koefisien sebesar 0,357 dan nilai T-statistik sebesar 4,121 (> 1,96), serta nilai P-Value sebesar 0,005 yang menunjukan bahwa hubungan antara EP dengan MW adalah signifikan. Dengan demikian hipotesis $\mathrm{H} 2$ dalam penelitian ini yang menyatakan bahwa ekspektasi pendapatan berpengaruh signifikan dan positif terhadap minat berwirausaha diterima

3. Ekspektasi pendapatan merupakan variabel yang lebih dominan dalam mempengaruhi minat berwirausaha yang ditunjukan dengan nilai koefisien yang diestimasi sebesar 0.357 .

\section{REFERENSI}

[1] Adhitama, P. Patria. 'Faktor yang Mempengaruhi Minat berwirausaha'. Skripsi Universitas Diponegoro, Semarang. 2004

[2] Mutis, T. 1995. Kewirausahaan yang Berproses. Grasindo.Jakarta.

[3] Wiratmo, M. 'Pengantar Kewiraswastaan, Kerangka Dasar Memasuki Dunia Bisnis'. BPFE-Yogyakarta. Yogyakarta. 2001

[4] Bandura, Albert. 'Perceived Self-efficacy in Cognitive Development and Functioning'. Educational Psychologist, 28(2), 117-14. 1993

[5] Zimmerer, Thomas W. \& Norman M. Scarborough. 'Kewirausahaan dan Manajemen Usaha Kecil'. Salemba Empat. Jakarta. 2008

[6] Santosa, Satria Bekti. 'Pengaruh Efikasi Diri (Belajar Kewirausahaan Terhadap Motivasi Berwirausaha Berbasis Teknologi (Siswa Program Keahlian Teknik Pemesinan Kelas XI SMK Muhammadiyah 3 Yogyakarta'. Skripsi. Universitas Negeri Yogyakarta. 2014

[7] Setiawan, Deden. 'Pengaruh Ekspektasi Pendapatan, Lingkungan Keluarga Dan Pendidikan Kewirausahaan Terhadap Minat Berwirausaha (Studi Kasus pada Mahasiswa Akuntansi Universitas Negeri Yogyakarta)'. Skripsi. Universitas Negeri Yogyakarta. 2016

[8] Akbar, Fitrah. 'Pengaruh Kepribadian, Motivasi dan Keluarga Terhadap Minat Mahasiswa Ekonomi Syariah Fakultas Ekonomi dan Bisnis Universitas Airlangga untuk Berwirausaha'. Skripsi. Universitas Airlangga. 2013

\section{JMTS|}

[9] Batubara, Amalia Tamara. Pengaruh Efikasi

Diri Dan Kompetensi Kewirausahaan Terhadap Minat Berwirausaha Pada Siswa/Siswi SMK Negeri 10 Medan. Skripsi. Universitas Sumatera Utara. 2016

[10] Henseler, J. 'Covariance-based Structural Equation Modeling: Foundations and Applications'. University of Cologne, Department of Marketing and Market Research. 2010. 